\section{Global burden of mental illness in agents fighting endemics}

\author{
Carga global da doença mental entre \\ trabalhadores no combate a endemias
}

\section{Carga global de las enfermedades mentales en agentes sanitarios que luchan contra endemias}

COMUNICAÇÃO BREVE

BRIEF COMMUNICATION
Maria Luiza Almeida Bastos 1

Thalyta Gleyane Silva de Carvalho 1

Marcelo José Monteiro Ferreira 1

doi: 10.1590/0102311X00157921

\begin{abstract}
Mental disorders are the main cause of the young and economically active population worldwide and in Brazil to live with disabilities, being an important public health problem nowadays. The objective was to estimate the burden of mental disorders among professionals working to combat endemic diseases in a state in northeastern Brazil. Medical records of workers linked to the Brazilian Ministry of Health in Ceará State and fighting endemic diseases were surveyed and, from this, a historical cohort was made. The individual quantification of absenteeism by mental disorders (ICD F-chapter referring to mental disorders) was conducted considering a period of about 35 years, from admission (the 1980s) to December 2017. The global burden of disease was measured by the YLD indicator (years lost to disability). Considering that no deaths due to mental disorders were observed, the YLL indicator (years of life lost) was composed. The high mental disorders burden in this group of workers stands out, whose mood disorders, including depression, conferred a YLD equal to 18.6. This represents just over 18 years of work lived with a disability. Our findings reinforce the need to implement surveillance and health promotion actions in workers to promote effective interventions capable of contributing to the reduction of morbidity in workers and economically active people.
\end{abstract}

Mental Disorders; Insecticides; Health Personnel

\section{Correspondence}

M. L. A. Bastos

Rua Dr. Gilberto Studart 1020, Fortaleza, CE 60192-095, Brasil.

mluiza@alu.ufc.br

${ }^{1}$ Universidade Federal do Ceará, Fortaleza, Brasil. 


\section{Introduction}

Mental disorders represent an important problem for public health. According to the Global Burden of Disease (GBD) study, mental disorders have been the second leading cause of years lived with disability (YLD) in the world 1, affecting the young and economically active population, 15 to 49 years 1, and negatively impacting the health of workers.

Evidence of the association of mental disorders with occupational hazards in some professional activities exist, including health workers 2 . Agents fighting endemics are health professionals involved in public health campaigns whose assignments involve several occupational risks such as actions in vacant lots, inspection of water tanks, and vector control with insecticides 3 .

Some studies have shown associations between exposure to insecticides and depressive episodes 4,5 . mental disorders such as anxiety and stress are prevalent in health professionals and related to feelings of dissatisfaction and devaluation and high demands 2,6.

Several doubts remain to be clarified regarding the relationship between work and mental disorders; however, investigating the mental disorders burden in working populations is necessary, since these causes have increasingly motivated disability benefits within social security in Brazil ${ }^{7}$.

The aim of this study was to investigate the mental disorders burden among professionals working to combat endemic diseases in a state in northeastern Brazil.

\section{Methods}

This study is part of the research entitled Global Burden of Disease in Agents to Combat Endemic Diseases in the State of Ceará. This is an exploratory study of a historical cohort compiled from the survey of medical records of workers fighting endemic diseases, job holders have attributes related to vector control. The medical records were surveyed to individually quantify absenteeism due to mental disorders from admission to December 2017, which covers a period of almost 35 years. As inclusion criteria, public workers linked to the Brazilian Ministry of Health, located in the state of Ceará and whose occupation is related to fighting endemic diseases, were selected. Professionals who work in administrative functions or who reported not having contact with insecticides in their professional practice were excluded from the research.

The outcome of this study was quantified in DALY (disability-adjusted life years), which is composed of two indicators: YLD and YLL (years of life lost), that is, years lost due to premature death. In this study, we have considered the quantification of days absent from work due to disability and deaths 8 , both motivated by mental disorders, broken down according to chapter $\mathrm{V}$ of the International Classification of Diseases, 10th edition (ICD-10) and its groupings F00 to F99, codes F10 (Mental and behavioral disorders due to alcohol use), F30-39 (Mood disorders) and F40-48 (Stress-related disorders) were used.

The global burden of disease was measured by the YLD indicator, considering that no deaths from mental disorders were recorded. The measurement of YLD is based on the number of mental disorders cases and its mean duration, and weight to each classification of the disease must be assigned using the following formula 8 : YLD = number of cases $\mathrm{X}$ mean duration of disability $\mathrm{X}$ weight. The weights were assigned according to the 2017 GBD study 9, being 0.57 ; 0.66 and 0.52 , respectively assigned to F10, F30-39 and F40-48.

This research is part of a project approved by the Ethics Committee for Research on Human Beings of the University of Fortaleza (opinion n. 2.216.806/2017, issued on August 14, 2017).

\section{Results}

During the survey of medical records, a total of 595 records were found, with an unbalanced proportion between men $(\mathrm{n}=584,98 \%)$ and women $(\mathrm{n}=11,2 \%)$. Thus, it was decided to exclude women from the analysis, since data relating to them could been a confounding factor. 
The following are the findings: YLD was 3,184.9; 1,732.9; 1,654.1 per 105 for mood disorders, stress-related disorders and mental disorders due to alcohol use, respectively.

Mental disorders accounted for $14.7 \%(n=86)$ of the incidence of sick leave in this occupational group over the period analyzed. From admission to the year 1996, there were no records of sick leave. After that date, the number of workers and the days away from work increased progressively. Absenteeism increased significantly during the third decade of work, as shown in Figure 1.

The causes that most impacted absenteeism were motivated by mood disorders (F30-39: 38.5\%), mental disorders due to the use of psychoactive substances (F10-19: 27.8\%) and stress-related disorders (F40-48: 26.6\%). Something noteworthy is that leaves were recurrent and often justified with more than one ICD. This finding directly contributed to the mental disorders burden, at the expense of YLD, since no deaths for these reasons occurred and the YLL indicator was disregarded.

In this specific occupational group, mood disorders have been responsible for a high burden of disease, corresponding to 18.6 DALY. Stress-related disorders accounted for 10.12 DALY, and mental disorders related to alcohol use was 9.66 DALY.

\section{Discussion}

This survey showed that mood disorders accounted for 18.6 DALY, followed by stress-related disorders, 10.12 DALY, and mental disorders related to alcohol abuse, 9.66 DALY. These findings corroborate the GBD results, demonstrating that mental disorders are the second leading cause of YLD in the world, only behind musculoskeletal disorders ${ }^{1}$. In Brazil, the same ranking 1 is found, reinforcing the importance of mental disorders in providing morbidity and disability.

\section{Figure 1}

Incidence of workers and absenteeism (on days absent from work) during the working life. State of Ceará, Brazil, from admission to 2017.

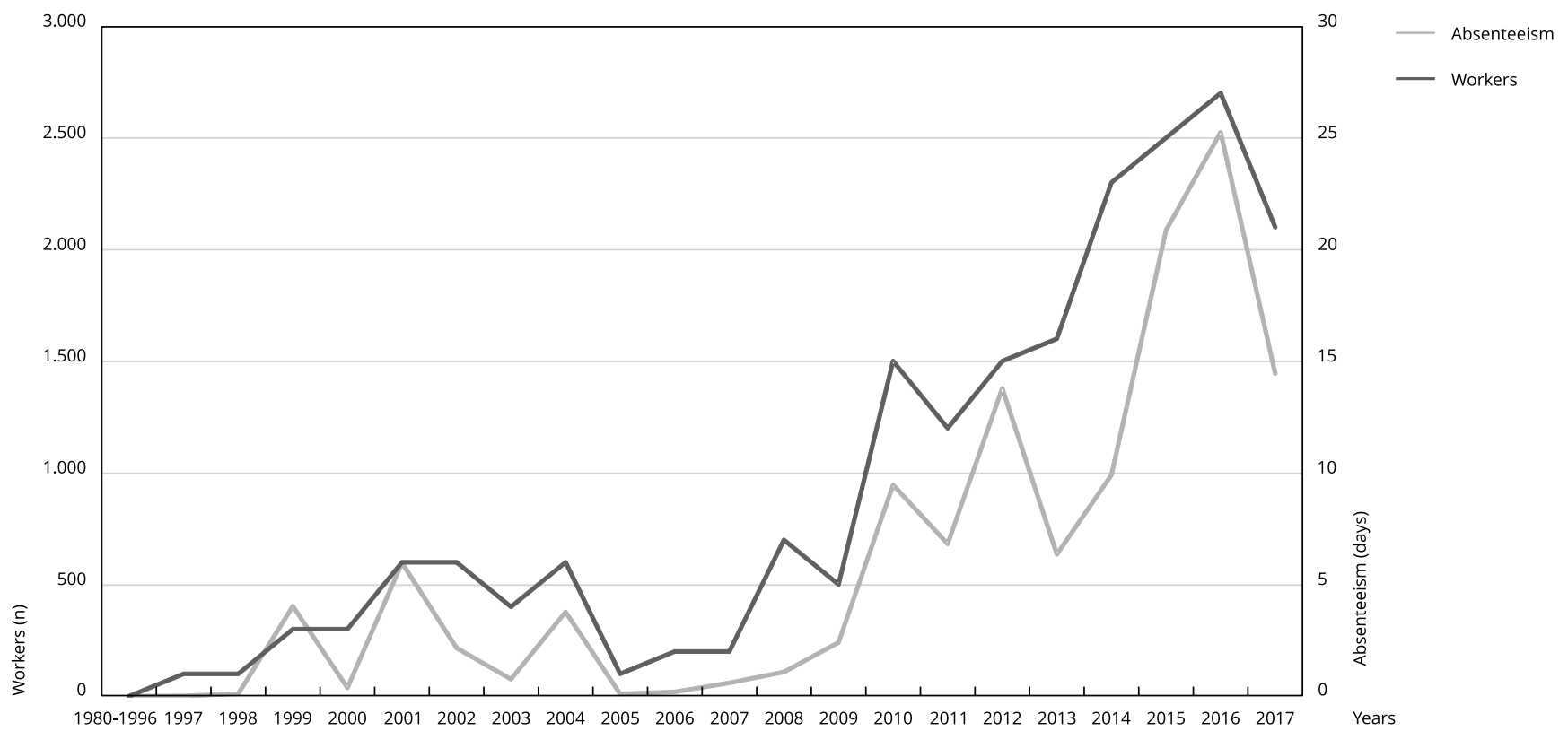


The analysis of DALY for mental disorders shows that these conditions are linked to disability, therefore to YLD 10. This outcome can also be evidenced with data from social security statistical yearbooks, which show that mental disorders are important causes of benefits for years, including long-term benefits 7 .

Mood disorders were responsible for almost 20 years of work lived with disability in the studied records. According to the social security legislation in force in Brazil, men can retire after 35 years of contribution 11, meaning that more than half of their professional life expectancy is affected by mental disorders, which negatively impacts these people's lives.

Stress-related disorders also has proved to be relevant in providing disabilities during working life, with YLD greater than 10 years. One of the possible hypotheses is related to the work process of the agents to combat endemic diseases, especially about the chronic management of unhealthy substances used in public health campaigns 12; work overload is another hypothesis, given the emerging diseases of public health importance in recent years 12,13 .

As for the years lived with disability due to alcohol use, there are reports on alcoholism in professionals who perform vector control 14. Discussions about the characteristics of this type of work exist, including distance from the family, professional devaluation and work with insecticides. Alcoholism has a close relationship with high mental demand jobs, dangerous jobs and socially underprivileged individuals 6 . Factors that instigate prevention activities and care for the health of these workers, since the use of alcohol was also an important factor in disability.

\section{Conclusion}

This study is a pioneer in the investigation of disease burdens in endemic fighting agents. Our results reinforce the existence of a high burden of mental disorders in workers combating vectors, showing the importance of mental disorders for workers' health. These causes have been responsible for an important fraction of the occupational history lived with morbidity, in addition to economic and social expenses. Expanding the use of this methodology to different professional categories is required. This will enable greater clarity for the planning and development of surveillance actions in occupational health. Interventions that contribute to the reduction of morbidity in economically active people should be guided by such studies, thus contributing to the economy. 


\section{Contributors}

M. L.A. Bastos contributed to the study conception, data analysis and interpretation and writing; and is responsible for all aspects of the work in ensuring the accuracy and completeness of any part of the work. T. G. S. Carvalho contributed to the writing and critical review of intellectual content. $\mathrm{M}$. J. M. Ferreira contributed to the study conception and data analysis and interpretation. All authors approved the final version to be published.

\section{Additional informations}

ORCID: Maria Luiza Almeida Bastos (0000-00032427-5896); Thalyta Gleyane Silva de Carvalho (0000-0003-1728-4719); Marcelo José Monteiro Ferreira (0000-0001-5187-4195).

\section{References}

1. Institute for Health Metrics and Evaluation. Global Burden of Disease Study 2019 (GBD 2019). https://vizhub.healthdata.org/gbdcompare/ (accessed on 24/Jun/2021).

2. Carvalho DB, Araújo TM, Bernardes KO. Transtornos mentais comuns em trabalhadores da atenção básica à saúde. Rev Bras Saúde Ocup 2016; 41:e17.

3. Candido AS, Ferreira RJ. Riscos à saúde e à segurança no trabalho do agente de combate às endemias do Município de Campos Sales, Ceará, Brasil. Ensaios e Ciência: Ciências Biológicas, Agrárias e da Saúde 2017; 21:52-7.

4. Suarez-Lopez JR, Hood N, Suárez-Torres J, Gahagan S, Gunnar MR, López-Paredes D. Associations of acetylcholinesterase activity with depression and anxiety symptoms among adolescents growing up near pesticide spray sites. Int J Hyg Environ Health 2019; 222:981-90.

5. Beard JD, Hoppin JA, Richards M, Alavanja MCR, Sandler ABDP, Kamel F. Pesticides exposure and self-reported incident depression among wives in the Agricututal Health Study. Environ Res 2013; 126:31-42.

6. Secretaria de Saúde do Estado da Bahia. Protocolo de atenção à saúde mental e trabalho. Salvador: Secretaria de Saúde do Estado da Bahia; 2014.

7. Minsitério da Economia. Anuário Estatístico da Previdencia Social. http://previdencia.gov. br/dados-abertos/dados-abertos-previdenciasocial/ (accessed on 20/May/2021).

8. Donev D, Zaletel-Kragelj L, Bjegovic V. Measuring the burden of disease: disability-adjusted life year (DALY). In: Burazeri G, ZaletelKragelj L, Petrela K, editors. Health investigation: analisys-planning-evaluation. 2nd Ed. Skopje: Jacobs Verlag; 2013. p. 393-416.

\section{Acknowledgments}

We would like to thank the Federal University of Ceará and the Brazilian Graduate Studies Coordinating Board (CAPES) for their research support.
9. Institute for Health Metrics and Evaluation. Global Burden of Disease Study 2017 (GBD 2017) disability weights. http://ghdx.health data.org/record/global-burden-disease-study2017-gbd-2017-disability-weights (accessed on 10/Jun/2019).

10. Bonadiman CSC, Passos VMA, Mooney M, Naghavi M, Melo APS. Carga dos transtornos mentais decorrentes do uso de substancias psicoativas no Brasil: Estudo de Carga Global de Doença, 1990-2015. Rev Bras Epidemiol 2017; 20 Suppl 1:191-204.

11. Brasil. Emenda Constitucional no 103, de 12 de novembro de 2019. Altera o sistema de previdência social e estabelece regras de transição e disposições transitórias. Diário Oficial da União 2019; 12 nov.

12. Augusto LGS, Gurgel AM, Costa AM, Diderichsen F, Lacaz FAC, Parra-Henao G, et al. Aedes aegypti control in Brazil. Lancet 2016; 387:1052-3.

13. Valle D, Nacif Pimenta D, Aguiar R. Zika, dengue e chikungunya: desafios e questões. Epidemiol Serv Saúde 2016; 25:419-22.

14. Lima EP, Lopes SMB, Amorim MIM, Araújo LHS, Neves KRT, Maia ER. Pesticide exposure and its repercussion in the health of sanitary agents in the State of Ceará, Brazil. Ciênc Saúde Colet 2009; 14:2221-30. 


\section{Resumo}

Os transtornos mentais são a principal causa de anos vividos com incapacidade entre a população jovem e economicamente ativa no mundo e no Brasil. Os impactos representam um problema importante para a saúde pública hoje. O objetivo do estudo foi de estimar a carga de transtornos mentais entre profissionais que trabalham no combate às doenças endêmicas em um estado do Nordeste brasileiro. Foi realizada uma coorte histórica com base na revisão de prontuários médicos dos profissionais que trabalham no combate às doenças endêmicas e vinculados ao Ministério da Saúde no Ceará. Procedemos à quantificação individual do absenteísmo por transtorno mental (CID, capitulo $F$, sobre transtornos mentais) ao longo de um período de cerca de 35 anos, desde a admissão (anos 1980) até dezembro de 2017. A carga global de doença foi medida pelo indicador anos vividos com incapacidade, considerando que não foram observados óbitos por transtorno mental, que constitui o indicador de anos de vida perdidos por morte prematura. Destaca-se a alta carga de transtorno mental nesse grupo de trabalhadores, cujos transtornos de humor, inclusive depressão, conferiam 18, 6 anos vividos com incapacidade, ou seja, mais de 18 anos de trabalho vividos com incapacidade. Nossos achados reforçam a necessidade de implementar medidas de vigilância e promoção da saúde nos trabalhadores para promover intervenções efetivas capazes de contribuir para a redução da morbidade entre trabalhadores e pessoas economicamente ativas.

Transtornos Mentais; Inseticidas; Pessoal de Saúde

\section{Resumen}

Los desórdenes mentales son la principal causa de años de vida vividos con discapacidad en la población joven y económicamente activa en el mundo $y$ en Brasil. Sus impactos representan un problema importante para la salud pública hoy en dia. El objetivo fue estimar la carga de los desórdenes mentales entre profesionales, que trabajan para combatir enfermedades endémicas en un estado del noreste brasileño. Se llevó a cabo con una cohorte histórica procedente de una investigación con registros médicos de trabajadores que luchaban contra enfermedades endémicas, relacionados con el Ministerio de Salud en Ceará. Se procedió a realizar una cuantificación individual del absentismo mediante desórdenes mentales (capitulo ICD $F$ que se refiere a los desórdenes mentales) durante un período de aproximadamente 35 años, desde la admisión (en los años de 1980) hasta diciembre de 2017. Se midió la carga global de la enfermedad mediante el indicador YLD (años perdidos por la discapacidad). Considerando que no se observaron muertes debido a las desórdenes mentales, que conforman el indicador YLL (años de vida perdidos). Destaca la alta carga de desórdenes mentales en este grupo de trabajadores, cuyos trastornos del comportamiento, incluyendo la depresión, confirió un YLD igual a 18,6. Esto representa algo más de 18 años de trabajo vividos con una discapacidad. Nuestros resultados refuerzan la necesidad de implementar acciones de vigilancia y promoción de la salud en los trabajadores, con el fin de promover intervenciones efectivas capaces de contribuir a la reducción de la morbilidad en trabajadores y gente activa económicamente.

Trastornos Mentales; Insecticidas;

Personal de Salud
Submitted on 25/Jun/2021

Final version resubmitted on 29/Nov/2021

Approved on 17/Dec/2021 